\title{
Employee perceptions of diversity management in the hospitality industry
}

Employee
perceptions of
diversity
management

Received 20 May 2021 Revised 28 August 2021 22 October 2021 Accepted 23 October 2021
Fevzi Okumus

Rosen College of Hospitality Management, University of Central Florida, Orlando, Florida, USA, and

Marissa Orlowski

School of Hospitality, Metropolitan State University of Denver, Denver, Colorado, USA

\begin{abstract}
Purpose - Diversity management is of great importance in the hospitality industry, resulting in a host of constructive consequences if managed effectively. However, there is a deficiency of investigation surrounding the outcomes of diversity management on the employees' attitudes and behavior in the hospitality industry. This research sought to investigate the influence of diversity management on workers' performance and conduct in the hospitality industry.

Design/methodology/approach - This quantitative study used survey data from 565 hospitality industry employees. Structural equation modeling was used to test the relationships from the research model.

Findings - This study identified a relationship between diversity management and positive workforce-related outcomes, including job performance, service innovation behavior and employee engagement in the hospitality industry.

Research limitations/implications - The findings of this study will push the confines of diversity management scholarship and initiate new paths of academic inquiry. Hospitality industry managers can also identify the benefits of effective diversity management as a consequence of this study.

Originality/value - This research contributes to the growing literature on diversity management as an essential aspect of human resources management in promoting positive employee attitudes and behaviors.
\end{abstract}

Keywords Diversity management, Employee engagement, Job performance, Service innovation behavior, Diversity and inclusion

Paper type Research paper

\section{Introduction}

Diversity is in the core of the hospitality industry based on its global nature and worldwide employment. Workforce diversity in the hospitality industry is related to a competitive advantage (Madera, 2018) and must be explored intricately to reap its full potential. Diversity management has received increased support from the corporate sector in the hospitality industry through investment in several diversity initiatives by major hospitality companies

(C) Trishna G. Mistry, Fevzi Okumus and Marissa Orlowski. Published in International Hospitality Review. Published by Emerald Publishing Limited. This article is published under the Creative Commons Attribution (CC BY 4.0) licence. Anyone may reproduce, distribute, translate and create derivative works of this article (for both commercial and non-commercial purposes), subject to full attribution to the original publication and authors. The full terms of this licence may be seen at http:// creativecommons.org/licences/by/4.0/legalcode

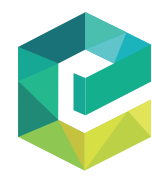

International Hospitality Review Emerald Publishing Limited DOI 10.1108/IHR-05-2021-0041 
(Gajjar and Okumus, 2018; Manoharan et al., 2021). Diversity management has received attention in recent years in becoming a consulting industry, with organizations partnering with both academics and practitioners to evaluate their diversity management initiatives (Pitts, 2009).

The foundation of diversity management literature lies in the discussion of workforce diversity. Diversity management research was initiated over two decades ago with the exploration of workforce diversity and its characteristics. It is crucial to understand how the hospitality sector manages workforce diversity due to the significant representation of minorities in the workforce (Kalargyrou and Costen, 2017). Table 1 highlights the demographic makeup of the hospitality and tourism industry in the United States.

Although diversity management research has garnered momentum in the past few years, the research stream focused on diversity management in the hospitality literature is far from mature. Furthermore, there is a stark theoretical and methodological gap in the diversity management stream of research between general management literature and hospitality management literature (Manoharan and Singal, 2017). Previous studies have proposed several benefits of effective diversity management in the hospitality industry (Kalargyrou and Volis, 2014; Kim, 2006; Manoharan et al., 2019). However, there is a lack of empirical evidence surrounding the consequences of diversity management in the hospitality industry. This gap could contribute to the scarcity of advanced and nuanced analysis regarding diversity management in the hospitality context. Additionally, there is limited research in assessing the impact of diversity management practices on organizational, work-related and operational outcomes (Pitts, 2009). The present research aims to contribute to the body of literature by analyzing the impact of effective diversity management practices and policies on hospitality employees' attitudes and behavior.

Hence, the purpose of this research is to analyze the impact of effective diversity management on employees' attitudes and behavior in the hospitality industry. This study seeks to investigate a relationship between diversity management and positive workforcerelated outcomes, including job performance, service innovation behavior and employee engagement in the hospitality industry. This investigation is crucial in the hospitality industry literature to establish the importance of diversity management as a concrete antecedent of positive employee-related and organizational outcomes (Ashikali and Groeneveld, 2015).

Table 1.

Demographic details of the hospitality and tourism industry workforce

\begin{tabular}{|c|c|c|c|c|}
\hline Employees & $\begin{array}{c}\text { Total employed in } \\
\text { the USA } \\
\text { (Thousands) }\end{array}$ & $\begin{array}{l}\text { Total } \\
\text { employed in } \\
\text { the USA }(\%)\end{array}$ & $\begin{array}{l}\text { Employed in the } \\
\text { hospitality and tourism } \\
\text { industry (Thousands) }\end{array}$ & $\begin{array}{l}\text { Employed in the } \\
\text { hospitality and } \\
\text { tourism industry (\%) }\end{array}$ \\
\hline $\begin{array}{l}\text { Total, } 16 \text { years } \\
\text { and over }\end{array}$ & 153,337 & 100 & 14,291 & 100 \\
\hline White & 120,216 & 78.4 & 10,675 & 74.7 \\
\hline \multirow{2}{*}{\multicolumn{5}{|c|}{ African }} \\
\hline & & & & \\
\hline $\begin{array}{l}\text { Hispanic or } \\
\text { Latino }\end{array}$ & 25,914 & 16.9 & 3,215 & 22.5 \\
\hline Asian & 9,507 & 6.2 & 972 & 6.8 \\
\hline Men & 81,422 & 53.1 & 7,002 & 49 \\
\hline Women & 71,915 & 46.9 & 7,288 & 51 \\
\hline \multicolumn{5}{|c|}{ Source(s): U.S. Bureau of Labor Statistics (2020) } \\
\hline
\end{tabular}




\section{Literature review}

\subsection{Workforce diversity and diversity management}

Diversity can be broadly defined as "a characteristic of social grouping that reflects the degree to which objective or subjective differences exist between group members" (Van Knippenberg and Schippers, 2007, p. 516). Furthermore, in alignment with the social identity theory, "a group is diverse if it is composed of individuals who differ on a characteristic on which they base their own social identity" (O'Reilly et al., 1998, p. 186). Traditionally, diversity has included merely race and gender diversity. The Diversity Task Force (Best Practices in Achieving Workforce Diversity, 2001) research suggests that a common misapprehension about diversity is that only some persons or groups are included under its umbrella, when in fact, precisely the opposite is true. Furthermore, Kapoor (2011) has insisted on a broader definition of diversity, including a variety of other characteristics. Diversity can be viewed as a multi-dimensional concept (Griggs and Louw, 1995) that consists of primary characteristics (nationality, age, ethnicity and gender) and secondary characteristics (educational level, work experience, tenure, personality, and social and economic backgrounds) (Hsiao et al., 2015).

Effective diversity management includes voluntary programs and practices initiated by organizations to ensure an inclusive work environment (Mor Barak et al., 2016). It includes fair policies related to human resources management and programs created and implemented to manage the diverse workforce that is a reality today (Manoharan et al., 2021). Diversity management is vital for the hospitality industry due to the demographic shifts in the workplace that have made a diverse labor force a crucial fact for the hospitality industry. While numerous advantages of a diverse labor force have been emphasized, merely including a diverse labor force with the sole purpose of maintaining a representative image is counterproductive and organizational leaders must strategically reduce inclusion barriers (Sabharwal, 2014). Effective diversity management that generates positive outcomes depends on the creation and implementation of diversity management practices and employees' perceptions of such practices (Garcia-Rodriguez et al., 2020).

Aytemiz Seymen (2006) assessed the different cross-cultural diversity management approaches and concluded no optimal method to manage cultural diversity successfully. Cultural diversity management practices need to be customized to the needs of the organization (Aytemiz Seymen, 2006). Pieterse et al. (2013) concluded that cultural diversity has a positive relationship with team performance consisting of learning approach-oriented members. McKay et al. (2008) found a climate of diversity could have a positive relationship with employee job performance through their study, including African American and Latino employees. Richard et al. (2007) suggested that when organizations pass beyond certain levels of organizational diversity, there is a positive impact on organizational performance.

Diversity management literature in the hospitality field has typically investigated either role evaluation or best practices (Kalargyrou and Costen, 2017). Strategic training, as part of the diversity management initiatives, has yielded positive results, including an increase in the perception of the importance of diversity (Wilborn and Weaver, 2002). Iverson (2000) recommended diversity management practices for hospitality leaders, including effective communication, respect and inclusion of employees' capabilities, beliefs and language preferences.

Madera (2013) recognized categories of primary diversity management practices, including diversity councils, training programs related to diversity and supplier diversity. He further emphasized the importance of support for minority groups, including women, and the LGBTQ (lesbian, gay, bisexual, transgender, queer) community, mentoring and networking for the employees, and overall cultural awareness. These were further updated by Gajjar and Okumus (2018) to include intergenerational programs, disability benefits and veteran benefits.

Like research on workforce diversity, research interest regarding diversity management has gathered attention in the last few years. The evolvement of research objectives in
Employee
perceptions of
diversity
management

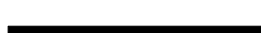


hospitality literature has recently progressed to the inquiry of diversity management outcomes. Madera et al. (2018) concluded that there is an increase in organizational attraction for hospitality industry employees based on the status of the organizations' diversity management programs. Hence, capitalizing on diversity management leads to enhanced organizational attraction and is mediated by person-organization fit.

Mistry (2019) developed a holistic diversity management measurement scale for the hospitality industry. Two factors of diversity management (diversity management initiatives and inclusive human resources management practices) were identified through the scale development process. Diversity management initiatives focused on the efforts of hospitality industry organizations to manage workforce diversity proactively, while inclusive HRM policies described fair and inclusive policies established by the hospitality industry organization as part of their diversity management efforts (Mistry, 2019). This study will utilize the two factors of diversity management to assess its impact on employees' attitudes and behavior.

\subsection{Job performance}

Job performance is the effectiveness of an employee in fulfilling the requirements of the job and accomplishing work-related goals efficiently (Babin and Boles, 1998; Roth et al., 2003). Extant research regarding job performance within general management and hospitality management scholarship has revealed several organizational factors that positively impact employee job performance. Li et al. (2012) indicated that leader-member exchange was positively linked to employee job performance. Additionally, human resources management consistently strengthened the relationship between leader-member exchange and work engagement. Increased work engagement and a sense of repaying the supervisors, as explained by the social exchange theory, may provide enhanced energy and a willingness to invest increased efforts, thus enhancing job performance (Bakker et al., 2007; Bakker and Leiter, 2010). Several studies from multiple industries have confirmed a positive connection between work engagement and job performance (Gottschalg and Zollo, 2007; Bakker and Leiter, 2010), including hotels (Salanova et al., 2005).

Sun et al. (2007) concluded a positive association between high-performance human resources practices (HPHRPs) and job productivity, which is an indicator of performance. Nadda et al. (2014) found that effective human resources management practices focusing on compensation, training, development, workplace freedom, information sharing, etc., have a positive impact on employees' performance. Additionally, high-performance work practices, including training, empowerment and reward, have a positive impact on job performance among hotel employees (Karatepe, 2013). Effective diversity management can be identified as an HPHRP (Shen et al., 2010) and can be positively associated with job performance in the workforce.

When managed effectively, diversity can improve growth and learning (Choi and Rainey, 2010). Hence, effective diversity management has been found to have a positive relationship with job performance (Choi and Rainey, 2010). Pitts (2009) also concluded a positive relationship between diversity management and work performance at the federal level in the United States. Similarly, Cho and Mor Barak (2008) found diversity management and inclusion significantly impacted job performance and commitment toward the organization. However, this investigation is vital, albeit lacking in hospitality industry research. This research proposes a direct positive connection between diversity management and job performance of hospitality industry employees.

H1a. Diversity management initiatives will have a direct positive relationship with job performance.

H1b. Inclusive HRM practices will have a direct positive relationship with job performance. 


\subsection{Service innovation behavior}

This research uses Chen's (2011) definition of service innovation as the development of novel and valuable concepts for improving service efficiency. Recent trends indicate that service industries, including the hospitality industry, rely on their workers to create innovative ideas regarding services being offered to guests (Hon, 2011). Service innovation behavior has been marked in the hospitality industry as an avenue for gaining a competitive edge and attaining sustainable growth (Dhar, 2016).

Chang et al. (2011) found a link between human resources management practices of hospitality firms and innovation. The degree to which HPHRPs demonstrate to the employees that their organization cares about them has a high impact on refining the connections between the employees and their organization and hence plays a significant role in generating desirable work-related behaviors (Dhar, 2015). Recent studies have linked the effectiveness of human resources management practices of organizations with producing creative work outcomes from their employees (Cooke and Saini, 2010). Furthermore, Dhar (2015) found a positive relationship between HPHRPs and the service innovation behavior of workers. Since diversity management is categorized as an HPHRP, it is also expected to have a positive linkage with service innovation behavior.

Furthermore, Jung and Yoon (2018) concluded that conflict management climate, as perceived by frontline employees in the hospitality industry, impacts employees' service innovation behavior. Baqutayan (2014) further argued innovation behavior could be promoted within an organization by managing constructive conflict. Based on the social identity theory, diversity management efforts are rooted in the concept of conflict management among a diverse group of employees (Choi and Rainey, 2014). Thus, diversity management, as a way of conflict management, should also have an impact on workers' service innovation behavior in the hospitality industry.

H2a. Diversity management initiatives will have a direct positive relationship with service innovation behavior.

H2b. Inclusive HRM policies will have a direct positive relationship with service innovation behavior.

\subsection{Employee engagement}

Schaufeli et al. (2002) identified employee engagement as "a positive, fulfilling, work-related state of mind that is characterized by vigor, dedication, and absorption" (p. 74). This definition will be used for this research as it highlights the employee being in a motivational state (Saks and Gruman, 2014). Employee engagement has been investigated in the hospitality industry context, albeit as an emerging concept (Lee and Ok, 2015). They found that several components of the psychological climate of the organization can be positively linked with employee engagement in the hospitality industry.

Lee and Ok (2016) further tied employee engagement with the leader-member exchange as an antecedent and organizational commitment as its consequence. Additionally, transformational leadership has also been found to have a positive influence on employee engagement in the hospitality industry (Buil et al., 2016). Employee engagement has not been directly linked with diversity management in the existing literature due to the developing nature of the research stream. Still, these findings highlight the importance of positive organizational factors in enhancing employee engagement. Diversity management has been identified as a positive organizational factor and linked with several desirable outcomes. This study aims to extend the literature to its impact on employee engagement as well.

Additionally, Presbitero (2017) concluded a positive association between human resources management practices and employee engagement among hotel workers. Hence, effective 
human resources management practices, including diversity management, can have a positive impact on employee engagement in the hospitality industry. There is still a gap in the literature in investigating the relationship between diversity management and employee engagement. Accordingly, this research proposes a direct positive relationship between diversity management and employee engagement among hospitality industry employees.

H3a. Diversity management initiatives will have a direct positive relationship with employee engagement.

H3b. Inclusive HRM policies will have a direct positive relationship with employee engagement.

\subsection{Mediating relationships}

Previous studies have suggested that employee engagement is one of the attitudinal factors that boost positive employee behavior (Jung and Yoon, 2018). Engaged workers are more creative and more productive (Bhatnagar, 2012). Chang et al. (2013) concluded a positive relationship between engagement and innovative behavior. Furthermore, engagement has also been related to positive outcomes, including better job performance (Halbesleben and Wheeler, 2008; Bakker and Bal, 2010).

Employee engagement has also been analyzed as a mediating variable between organizational characteristics and organizational outcomes numerous times in general management literature (Schaufeli and Bakker, 2004; Saks, 2006; Salanova and Schaufeli, 2008; Aggarwal et al., 2010; Chughtai and Buckley, 2011; Bhatnagar, 2012). Employee engagement mediated the connection between job resources and turnover intention (Schaufeli and Bakker, 2004). Furthermore, engagement mediated the association between job resources and proactive behavior (Salanova and Schaufeli, 2008).

Chugtai and Buckley (2011) concluded a mediating relationship between organizational characteristics such as trust and job performance via employee engagement. Garg and Dhar (2017) found that the relationship between leader-member exchange and service innovation behavior was mediated by work engagement. Furthermore, Jung and Yoon (2018) concluded a mediating link between an organizational climate of conflict management and service innovation behavior via employee engagement. These findings suggest that employee engagement is an appropriate mediator between organizational characteristics and positive employee behavior (Salanova and Schaufeli, 2008) (see Figure 1).

The literature on employee engagement, job performance and service innovation behavior suggests that engaged employees will tend to respond by performing better at their job and by showcasing more acts of service innovation behavior. Consequently, this study proposes that employee engagement will mediate the relationships between diversity management and job performance and diversity management and service innovation behavior. Based on the existing literature on diversity management, employee engagement, job performance and service innovation behavior, the following hypotheses have been proposed.

H4a. Employee engagement will mediate the relationship between diversity management initiatives and job performance.

$H 4 b$. Employee engagement will mediate the relationship between inclusive HRM policies and job performance.

H5a. Employee engagement will mediate the relationship between diversity management initiatives and service innovation behavior.

H5b. Employee engagement will mediate the relationship between inclusive HRM policies and service innovation behavior. 

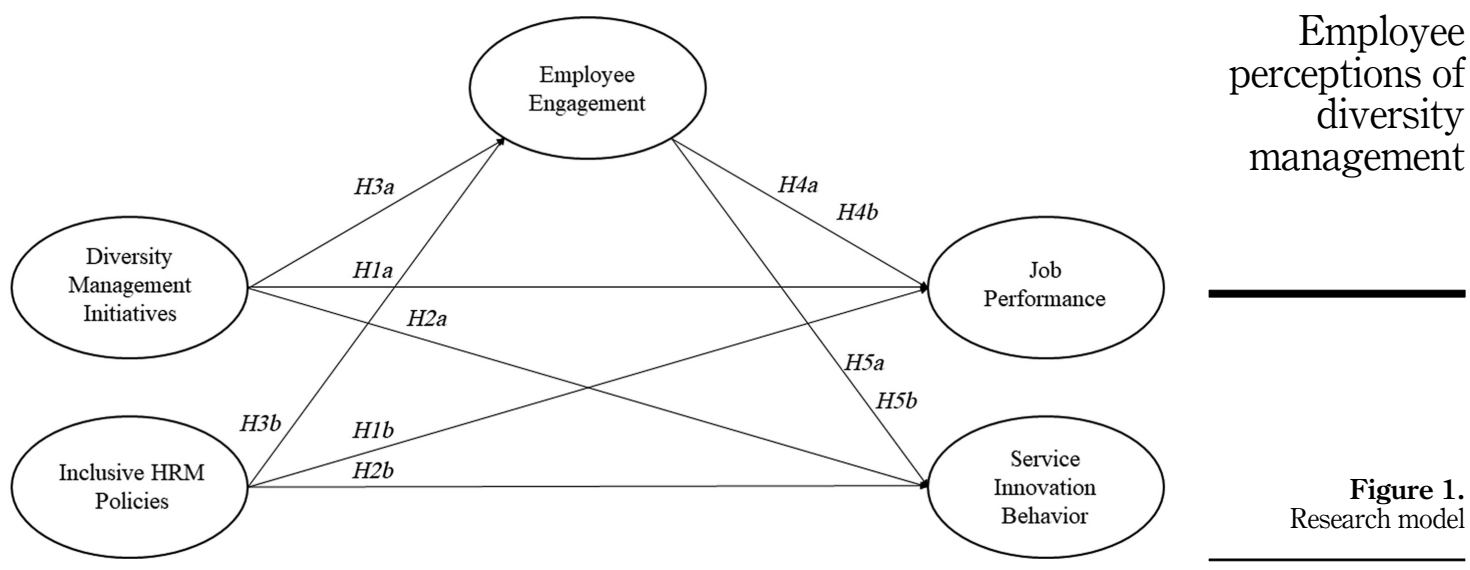

\section{Methodology}

\subsection{Measures and sample}

A quantitative study was conducted to assess the research model. Data was collected through a survey of hospitality industry employees to investigate the direct and indirect impacts of diversity management on job performance, service innovation behavior and employee engagement within the hospitality industry.

Diversity management was measured using its two factors, diversity management initiatives (24 items) and inclusive human resources management policies (six items) developed by Mistry (2019). A sample item for diversity management initiatives included, "My organization invests its resources in diversity management-based training and development for all employees." Furthermore, "Employees from different backgrounds are treated fairly in my organization" was an example of inclusive human resources management practices. Cronbach's alpha was 0.971 for the 24 items of diversity management initiatives and 0.853 for the six items of inclusive HRM policies.

Job performance was measured using six items adopted by Chiang and Hsieh (2012) with a Cronbach's alpha value of 0.907 , suggesting adequate internal consistency (Field, 2013). Sample item included "I meet performance standards and expectations of my job." Similar to previous efforts to measure employee service innovation behavior, a five-measure item developed by $\mathrm{Hu}$ et al. (2009) with appropriate internal consistency (Cronbach's alpha $=0.928$ ) was used. "At work, I seek new service techniques and methods" was a sample item. Employee engagement was measured using the nine-item Utrecht Work Engagement Scale (UWES-9) developed by Schaufeli et al. (2006) and with a Cronbach's alpha value of 0.897 . A sample item was "I am enthusiastic about my job."

All items in the survey were measured on a scale of $1-7$, where 1 was "strongly disagree" and 7 was "strongly agree." The final part of the survey included demographic information about the respondents, including their gender, age, education, income and race. Additionally, two attention check questions were included in the survey to maintain the quality of the data. The attention check questions were "I will select neither agree nor disagree for this statement" and were placed twice throughout the survey.

The sampling frame included hospitality industry employees at least 18 years old and who had been employed with their current company for at least 12 months (Hight et al., 2019). The survey was created and hosted using Qualtrics, and MTurk was used to distribute the survey and collect responses. Surveys that did not pass the attention check questions were 
not included in the final data set. Duplicate respondents were deleted by comparing the computer IP addresses of the respondents. A total of 1,363 completed responses were collected, out of which 587 passed the attention check questions and were used for additional data screening. The final data set included 565 responses.

\subsection{Data analysis}

The data collected from the Qualtrics survey was coded and entered into SPSS v.24 and Amos v.24 software. The data were screened to assess any missing data, outliers, and deviations from normality or linearity, as recommended by Hair et al. (2010). The internal consistency of each scale was assessed using Cronbach's alpha. Descriptive statistics were analyzed to evaluate the profile of the sample. Exploratory factor analysis (EFA) was conducted to validate the newly developed diversity management scale and its factors. The measurement and structural models were then assessed using confirmatory factor analysis (CFA) and structural equation modeling (SEM). CFA allowed the confirmation of the theorized model by assessing the overall fit before the SEM analysis was conducted (Hair et al., 2010). SEM can examine a series of dependence relationships simultaneously (Hair et al., 2010) and was hence deemed appropriate for this study. Convergent and discriminant validities of the measurement model were also assessed. Additionally, mediation analyses using bootstrapping were used to test the relative size of the mediated paths vs the direct paths (Iacobucci et al., 2007; Hayes, 2009).

\section{Results}

The first step of the analysis was to screen the data for univariate and multivariate outliers. Descriptive statistics for the items used in CFA and SEM analyses were analyzed to ensure there were no violations of the necessary assumptions of normality, homoscedasticity and linearity. A total of 1,363 responses were collected, and 68 were deleted based on responses to one or both of the screening questions. An additional 567 were deleted for failure to pass both the attention check questions, and 154 were deleted for incomplete data or based on descriptive statistics. Responses that passed only one of the two attention check questions were also discarded. The final dataset contained 565 cases. All the constructs included in the study had Cronbach's alpha values greater than 0.7 as desirable for adequate internal consistency (Hair et al., 2010).

\subsection{Demographic information}

The personal demographic information of the respondents was analyzed and is displayed in Table 2. The sample was split fairly evenly in terms of gender, and a little over half $(52.6 \%)$ of the respondents were male. About $80 \%$ of the respondents were under 40 years of age, a reasonably accurate representation of the hospitality industry (U.S. Bureau of Labor Statistics, 2020). Nearly half $(46.9 \%)$ of the respondents had a 4-year college degree and $15.8 \%$ had a master's degree. The respondents were distributed relatively evenly in all the income brackets provided as options. About $60 \%$ of the respondents were White/Caucasian, while about $20 \%$ were Asian, making up the largest two races in the sample.

\subsection{Exploratory factor analysis}

EFA was conducted with maximum likelihood extraction and Promax rotation to refine the diversity management measurement scale and explore its dimensions $(\mathrm{KMO}=0.965$; Bartlett's test of sphericity $\chi^{2}=5368.708$ [df $\left.=435, p<0.001\right]$ ). The rotated factor solution replicated the individual item loadings from the original scale, further confirming a two-factor solution (variance explained $=59.9 \%$ ). The factor loadings ranged from 0.609-0.902. The 


\begin{tabular}{|c|c|c|c|c|}
\hline Variable & Category & Frequency & Percentage & Employee \\
\hline \multirow[t]{4}{*}{ Gender } & Male & 297 & 52.6 & diversity \\
\hline & Female & 265 & 46.9 & \\
\hline & Other & 1 & 0.2 & management \\
\hline & Prefer not to answer & 2 & 0.4 & \\
\hline \multirow[t]{6}{*}{ Age } & $20-29$ & $23 \overline{4}$ & 41.4 & \\
\hline & $30-39$ & 213 & 37.7 & \\
\hline & $40-49$ & 70 & 12.4 & \\
\hline & $50-59$ & 30 & 5.3 & \\
\hline & $60-69$ & 17 & 3 & \\
\hline & $70-79$ & 1 & 0.2 & \\
\hline \multirow[t]{8}{*}{ Education } & Less than high school & 1 & 0.2 & \\
\hline & High School/GED & 38 & 6.7 & \\
\hline & Some college & 103 & 18.2 & \\
\hline & 2-year college degree & 52 & 9.2 & \\
\hline & 4-year college degree & 265 & 46.9 & \\
\hline & Master's degree & 89 & 15.8 & \\
\hline & Doctoral degree & 6 & 1.1 & \\
\hline & Professional degree (JD, MD) & 11 & 1.9 & \\
\hline \multirow[t]{9}{*}{ Income } & Below $\$ 20,000$ & 59 & 10.4 & \\
\hline & $\$ 20,000-\$ 29,999$ & 82 & 14.5 & \\
\hline & $\$ 30,000-\$ 39,999$ & 106 & 18.8 & \\
\hline & $\$ 40,000-\$ 49,999$ & 80 & 14.2 & \\
\hline & $\$ 50,000-\$ 59,999$ & 81 & 14.3 & \\
\hline & $\$ 60,000-\$ 69,999$ & 51 & 9 & \\
\hline & $\$ 70,000-\$ 79,999$ & 49 & 8.7 & \\
\hline & $\$ 80,000-\$ 89,999$ & 24 & 4.2 & \\
\hline & $\$ 90,000$ or more & 33 & 5.8 & \\
\hline \multirow[t]{8}{*}{ Race/Ethnicity } & Black/African American & 42 & 7.4 & \\
\hline & Asian & 107 & 18.9 & \\
\hline & Hispanic or Latino & 36 & 6.4 & \\
\hline & Native American & 25 & 4.4 & \\
\hline & Pacific Islander & 1 & 0.2 & \\
\hline & White/Caucasian & 336 & 59.5 & Table 2. \\
\hline & Two or more races & 14 & 2.5 & Demographic details of \\
\hline & Other & 4 & 0.7 & respondents \\
\hline
\end{tabular}

first factor included 24 items focusing on diversity management initiatives, and the second factor contained six items related to inclusive HRM policies, consistent with the scale. The pattern matrix of the diversity management scale is highlighted in Table 3.

\subsection{Confirmatory factor analysis}

CFA was conducted using the maximum likelihood (MLM) estimator. The results suggested a good fit to the model $\left(\chi^{2}=2831.773, \mathrm{df}=1,165, p<0.01, \mathrm{CFI}=0.910, \mathrm{TLI}=0.905\right.$, RMSEA, 0.050 , SRMR = 0.059). As highlighted in Table 4, the square root of each AVE was higher than the correlations with other constructs confirming appropriate discriminant validity (Fornell and Larcker, 1981). The diagonal numbers in bold represent the square root of the average variance extracted (AVE). The remaining numbers show correlations.

The standardized factor loadings, AVE estimates and construct reliabilities are shown in Table 5. The standardized factor loadings were all larger than 0.50 as desired, ranging from 0.517 to 0.883 and significant at $p<0.001$. The $\mathrm{CR}$ values for each of the constructs were greater than 0.7 as desired (DMI $=0.982, \mathrm{IHRMP}=0.878, \mathrm{JP}=0.887, \mathrm{SIB}, 0.878, \mathrm{EE}=0.925$ ). Furthermore, the AVE estimates for each of the constructs were greater than the required 


\section{IHR}

\begin{tabular}{|c|c|c|}
\hline & & \\
\hline & DMI & IHRMP \\
\hline DMI1 & 0.696 & \\
\hline DMI2 & 0.609 & \\
\hline DMI3 & 0.699 & \\
\hline DMI4 & 0.768 & \\
\hline DMI5 & 0.710 & \\
\hline DMI6 & 0.718 & \\
\hline DMI7 & 0.765 & \\
\hline DMI8 & 0.756 & \\
\hline DMI9 & 0.847 & \\
\hline DMI10 & 0.722 & \\
\hline DMI11 & 0.686 & \\
\hline DMI12 & 0.808 & \\
\hline DMI13 & 0.902 & \\
\hline DMI14 & 0.815 & \\
\hline DMI15 & 0.742 & \\
\hline DMI16 & 0.706 & \\
\hline DMI17 & 0.898 & \\
\hline DMI18 & 0.853 & \\
\hline IHRMP1 & & 0.799 \\
\hline IHRMP2 & & 0.601 \\
\hline IHRMP3 & & 0.663 \\
\hline IHRMP4 & & 0.646 \\
\hline DMI19 & 0.632 & \\
\hline DMI20 & 0.675 & \\
\hline DMI21 & 0.677 & \\
\hline DMI22 & 0.691 & \\
\hline IHRMP5 & & 0.862 \\
\hline IHRMP6 & & 0.617 \\
\hline DMI23 & 0.656 & \\
\hline DMI24 & 0.806 & \\
\hline
\end{tabular}

Table 3.

Note(s): Extraction Method: Maximum Likelihood; Rotation Method: Promax with Kaiser Normalization ${ }^{\mathrm{a}}$;

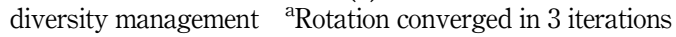

\begin{tabular}{llccccccccc}
\hline & \multicolumn{1}{c}{ CR } & AVE & MSV & MaxR(H) & DMI & EE & JP & IHRMP & SIB \\
\cline { 2 - 9 } & & DMI & 0.982 & 0.699 & 0.434 & 0.983 & 0.836 & & & \\
& EE & 0.925 & 0.578 & 0.556 & 0.929 & 0.659 & 0.761 & & & \\
Table 4. & JP & 0.887 & 0.573 & 0.260 & 0.902 & 0.116 & 0.367 & 0.757 & & \\
Convergent and & IHRMP & 0.878 & 0.547 & 0.393 & 0.881 & 0.616 & 0.627 & 0.510 & 0.739 & \\
discriminant validities & SIB & 0.878 & 0.591 & 0.556 & 0.883 & 0.634 & 0.745 & 0.338 & 0.470 & 0.769 \\
\hline
\end{tabular}

threshold of 0.5 (DMI $=0.699$, IHRMP $=0.574, \mathrm{JP}=0.573, \mathrm{SIB}, 0.591, \mathrm{EE}=0.578)$. Standardized loadings for all items, along with CR and AVE for all constructs, adequately satisfied the desired criteria. Thus, convergent validity and reliability were confirmed.

\subsection{Structural equation modeling}

The direct and indirect relationships were then assessed using SEM. The results for the various fit indices used to assess the structural model indicate that the proposed model provides a good fit to the data model $\left(\chi^{2}=2831.773\right.$, df $=1,165, p<0.01$, CFI $=0.910$, $\mathrm{TLI}=0.905$, RMSEA, 0.050, SRMR $=0.059$ ). The standardized path coefficients, $t$-values and results of the direct relationships (Hypotheses $1 \mathrm{a}-3 \mathrm{~b}$ ) are discussed in Table 6 . 


\begin{tabular}{|c|c|c|c|c|c|}
\hline Construct & Item & Standardized loadings & $\mathrm{CR}$ & AVE & Employee \\
\hline \multirow[t]{24}{*}{ Diversity management initiatives } & DMI1 & 0.754 & \multirow[t]{24}{*}{0.982} & \multirow[t]{24}{*}{0.699} & diversity \\
\hline & DMI2 & 0.762 & & & management \\
\hline & DMI3 & 0.810 & & & management \\
\hline & DMI4 & 0.816 & & & \\
\hline & DMI5 & 0.844 & & & \\
\hline & DMI6 & 0.848 & & & \\
\hline & DMI7 & 0.798 & & & \\
\hline & DMI8 & 0.856 & & & \\
\hline & DMI9 & 0.877 & & & \\
\hline & DMI10 & 0.883 & & & \\
\hline & DMI11 & 0.862 & & & \\
\hline & DMI12 & 0.854 & & & \\
\hline & DMI13 & 0.849 & & & \\
\hline & DMI14 & 0.819 & & & \\
\hline & DMI15 & 0.794 & & & \\
\hline & DMI16 & 0.755 & & & \\
\hline & DMI17 & 0.829 & & & \\
\hline & DMI18 & 0.878 & & & \\
\hline & DMI19 & 0.876 & & & \\
\hline & DMI20 & 0.837 & & & \\
\hline & DMI21 & 0.879 & & & \\
\hline & DMI22 & 0.867 & & & \\
\hline & DMI23 & 0.837 & & & \\
\hline & DMI24 & 0.860 & & & \\
\hline \multirow{6}{*}{ Inclusive HRM policies } & IHRMP1 & 0.768 & \multirow[t]{6}{*}{0.878} & \multirow[t]{6}{*}{0.547} & \\
\hline & IHRMP2 & 0.767 & & & \\
\hline & IHRMP3 & 0.734 & & & \\
\hline & IHRMP4 & 0.669 & & & \\
\hline & IHRMP5 & 0.773 & & & \\
\hline & IHRMP6 & 0.721 & & & \\
\hline \multirow{6}{*}{ Job performance } & JP1 & 0.784 & \multirow{6}{*}{0.887} & \multirow[t]{6}{*}{0.573} & \\
\hline & $\mathrm{JP} 2$ & 0.796 & & & \\
\hline & JP3 & 0.772 & & & \\
\hline & JP4 & 0.839 & & & \\
\hline & JP5 & 0.517 & & & \\
\hline & JP6 & 0.788 & & & \\
\hline \multirow[t]{5}{*}{ Service innovation behavior } & SIB1 & 0.721 & \multirow[t]{5}{*}{0.878} & \multirow[t]{5}{*}{0.591} & \\
\hline & SIB2 & 0.744 & & & \\
\hline & SIB3 & 0.762 & & & \\
\hline & SIB4 & 0.837 & & & \\
\hline & SIB5 & 0.777 & & & \\
\hline \multirow[t]{9}{*}{ Employee engagement } & EE1 & 0.761 & \multirow[t]{9}{*}{0.925} & \multirow[t]{9}{*}{0.578} & \\
\hline & EE2 & 0.800 & & & \\
\hline & EE3 & 0.818 & & & \\
\hline & EE4 & 0.788 & & & \\
\hline & EE5 & 0.793 & & & \\
\hline & EE6 & 0.769 & & & \\
\hline & EE7 & 0.711 & & & Table 5. \\
\hline & EE8 & 0.766 & & & Item loadings, \\
\hline & EE9 & 0.620 & & & reliability and validity \\
\hline
\end{tabular}


Hypothesis 1a was partially supported as there is a significant relationship between diversity management initiatives and job performance. Still, contrary to the proposed positive relationship, the results revealed a negative relationship $(\beta=-0.318, p<0.05)$. This indicates that diversity management initiatives were negatively associated with job performance among hospitality industry employees. The results confirm that inclusive HRM policies have a direct positive relationship with job performance, supporting hypothesis $1 \mathrm{~b}(\beta=0.706$, $p<0.05$ ). Furthermore, diversity management initiatives have a direct positive relationship with service innovation behavior, thus confirming hypothesis $2 \mathrm{a}(\beta=0.556, p<0.05)$. The relationship between inclusive HRM policies and service innovation behavior was also statistically significant, and hypothesis $2 \mathrm{~b}$ was supported $(\beta=0.127, p<0.05)$. Both diversity management initiatives $(\beta=0.439, p<0.05)$ and inclusive HRM policies $(\beta=0.357, p<0.05)$ had direct positive relationships with employee engagement, supporting hypotheses $3 \mathrm{a}$ and $3 \mathrm{~b}$. Hence, other than the relationship between diversity management initiatives and job performance, both diversity management initiatives and inclusive HRM policies are positively associated with job performance, service innovation behavior and employee engagement.

\subsection{Mediation analysis}

Mediation analysis using 5000 bootstrapped samples and with a $95 \%$ confidence interval (CI) was conducted. The results of the mediation analysis and indirect effects (Hypotheses $4 a-5 b$ ) are displayed in Table 7 . Diversity management initiatives had a significant indirect relationship with job performance via employee engagement $(95 \% \mathrm{CI}=0.056,0.204)$. Since the $95 \%$ CI did not include zero, statistical significance is established (Hayes, 2013), and hypothesis 4a was supported.

Furthermore, inclusive HRM policies also had a significant indirect relationship with job performance via employee engagement $(95 \% \mathrm{CI}=0.053,0.162)$, and hypothesis $4 \mathrm{~b}$ was supported. Additionally, employee engagement mediated the relationship between diversity management initiatives and service innovation behavior $(95 \% \mathrm{CI}=0.191,0.365)$ and between inclusive HRM policies and service innovation behavior $(95 \% \mathrm{CI}=0.134,0.323)$. Thus, hypotheses $5 \mathrm{a}$ and $5 \mathrm{~b}$ were also supported. This indicates that employee engagement mediated the relationships between diversity management initiatives and inclusive HRM policies and job performance and service innovation behavior as outcomes.

Table 6.

Results of direct relationships

\begin{tabular}{lccrl}
\hline Hypothesis & Standard estimate & Standard error & $t$-value & Result \\
\hline H1a: DMI - JP & $-0.318^{* * * *}$ & 0.045 & -7.100 & Partially supported \\
H1b: IHRMP - JP & $0.706^{* * * *}$ & 0.043 & 16.496 & Supported \\
H2a: DMI - SIB & $0.556^{* * * *}$ & 0.044 & 12.529 & Supported \\
H2b: IHRMP - SIB & $0.127^{* * *}$ & 0.048 & 2.659 & Supported \\
H3a: DMI - EE & $0.439^{* * * *}$ & 0.042 & 10.520 & Supported \\
H3b: IHRMP - EE & $0.357^{* * * *}$ & 0.046 & 7.795 & Supported \\
\hline
\end{tabular}

\begin{tabular}{lcccc}
\hline & & \multicolumn{2}{c}{$95 \%$ CI } & \\
Hypothesis & Standard estimate & Low & High & Result \\
\hline H4a: DMI - EE - JP & 0.121 & 0.056 & 0.204 & Supported \\
H4b: IHRMP - EE - JP & 0.098 & 0.053 & 0.162 & Supported \\
H5a: DMI - EE - SIB & 0.270 & 0.191 & 0.365 & Supported \\
H5b: IHRMP - EE - SIB & 0.219 & 0.134 & 0.323 & Supported \\
\hline
\end{tabular}

Table 7.

Mediation analysis 


\section{Conclusions and discussion}

\subsection{Conclusions}

The purpose of this study was to analyze the relationship between diversity management and job performance, service innovation behavior and employee engagement of hospitality industry employees. Diversity management initiatives were found to have a significant negative relationship with job performance, partially supporting the hypothesis. Previous research has established that improving employees' job performance requires leadership and dedication from the organization (Sabharwal, 2014). Hence, merely introducing programs and insisting on employees to participate in the initiatives, without an appropriate contingency plan to make up for the productivity, can only negatively impact job performance. This idea can clarify the discrepancy between the initially hypothesized relationship and the actual conclusion that emerged during this study. Although programs that stimulate an inclusive environment and are instrumental in reducing interpersonal conflicts are beneficial (Choi and Rainey, 2014), appropriate measures must be taken to compensate for the time and resources spent participating in such initiatives.

Inclusive HRM policies were positively and significantly linked with job performance, supporting the hypothesis. Since HPHRPs have been positively linked with job performance (Sun et al., 2007), it is understandable for inclusive HRM policies related to diversity management to be positively associated with job performance. Nadda et al. (2014) also found fair policies related to compensation, hiring and promotions as contributing factors in enhancing employees' job performance. Hence, the inclusive HRM dimension of diversity management is duly linked with job performance in the hospitality and tourism industry, as supported by previous literature (Choi and Rainey, 2010).

Diversity management initiatives were concluded to have a direct positive relationship with service innovation behavior, as previously hypothesized. A supportive work environment and leadership commitment included in the diversity management initiatives dimension of diversity management have been found to positively impact service innovation behavior (Martins and Terblanche, 2003). A conflict management climate has been identified as a critical contributor to enhancing employees' service innovation behavior in the hospitality industry (Jung and Yoon, 2018). Since diversity management initiatives are ingrained within conflict management, diversity management initiatives have a positive impact on service innovation behavior.

Service innovation behavior was also significantly linked with the inclusive HRM policies dimension of diversity management. This relationship was the weakest among the hypothesized relationships, although it was statistically significant. The research on enhancing service innovation behavior is rooted in the concept of a supportive work environment and the ability and freedom for the employees to innovate (Reade and Lee, 2016). However, fair and inclusive human resources management policies regarding the fundamental human resources functions of compensation and hiring have not been linked with service innovation behavior in the literature. Organizations that practice inclusive HRM policies may have an impact on the performance of the employees' core job duties but do not necessarily have a superior impact on service innovation behavior, which is not included in their essential job functions.

Diversity management initiatives were established to have a significant positive relationship with employee engagement. Hence, the proposed hypothesis was supported in this instance. Karatepe and Olugbade (2009) found that employee engagement is positively affected by job resources, organizational environment and psychological climate in the hotel sector (Lee and Ok, 2015). The items included in the diversity management initiatives dimension are rooted in organizational characteristics and commitment to diversity management from the organization. Hence, the positive relationship between diversity management initiatives and employee engagement can be explained based on previous research.
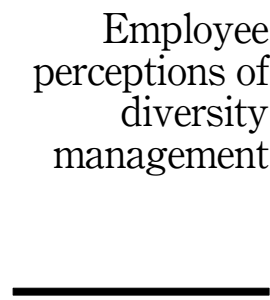
Employee engagement was also found to have a significant positive relationship with inclusive HRM policies dimension of diversity management, in alignment with the hypothesis. In addition to organizational factors, human resources practices have been known to increase employee engagement in the hotel industry (Presbitero, 2017). Since the items in inclusive HRM policies are focused on human resources management within the organization, there is ample justification to support the relationship between inclusive HRM policies and employee engagement.

Regarding the indirect mediating relationships, all four proposed hypotheses were supported since employee engagement has been identified as an attitudinal factor in generating positive employee behavior (Jung and Yoon, 2018). The relationship between diversity management initiatives and job performance was mediated by employee engagement. It is vital to note that the direction of the direct relationship between diversity management initiatives and job performance was negative, and introducing employee engagement as a mediator altered the direction of the indirect relationship. Hence, it can be concluded that employee engagement was a missing attitudinal factor in the relationship between diversity management initiatives and job performance.

The relationship between inclusive HRM policies and job performance was also mediated by employee engagement. Research has also suggested that employee engagement is an effective mediator between organizational characteristics and positive employee behaviors (Salanova and Schaufeli, 2008). This can explain that employee engagement further mediated the relationship between diversity management initiatives and service innovation behavior. Lastly, there was a significant indirect relationship between inclusive HRM policies and service innovation behavior through employee engagement.

\subsection{Theoretical implications}

This research provides numerous theoretical implications. This study advances the scholarship of diversity management beyond an assumptive approach (Pitts, 2009). The findings provide empirical evidence for the concepts described by researchers who have suggested that diversity management is beneficial to organizations and can be a source of competitive advantage (Yang and Konrad, 2011). This research advances the literature on diversity management further by moving beyond the assumptive idea that diversity management could be beneficial for the hospitality industry. This study provides empirical proof that diversity management is indeed vital for positive outcomes in the hospitality industry.

Additionally, this research concludes that diversity management mainly has a positive effect on desirable employee-related outcomes. The findings from the hypotheses testing further extend the body of knowledge on diversity management in the hospitality context by establishing a positive link between diversity management dimensions, job performance, service innovation behavior and employee engagement. The mediating effects of employee engagement further contribute to the literature by confirming that organizational factors can lead to attitudinal impacts, which eventually have an impact on the employees' behaviors (Salanova and Schaufeli, 2008) based on the social exchange theory.

\subsection{Practical implications}

This research provides many practical implications for the hospitality industry. It has been concluded that effective diversity management generates enhanced organization attraction (Madera et al., 2018), innovative ideas and a positive image for the organization (Ineson et al., 2013). Additionally, effective diversity management can also have a positive influence on an organization's financial performance (Singal, 2014). This research confirms the findings of previous research and establishes diversity management as an antecedent to positive 
attitudes and behaviors of hospitality and tourism industry employees. Diversity management is directly related to positive employee attitudes and behavior in the hospitality industry, and managers can utilize these findings to create favorable outcomes for their organizations.

Hospitality industry organizations must note that diversity management positively influences its employees' job performance, service innovation behavior and engagement. The findings not only encourage hospitality industry organizations to evaluate and enhance their diversity management efforts because of their impact on job performance and employee engagement, but they also provide practical evidence regarding the positive influence of diversity management on service innovation behavior. Managers do not need to "rely on gut feeling, speculation, and their own limited experience about the keys to innovation success" (Ottenbacher and Gnoth, 2005, p. 206) anymore.

Hospitality industry organizations can learn that basic compliance with the laws is not enough anymore. A more novel approach regarding their diversity management efforts is required to generate positive outcomes. A passive approach to diversity and diversity management may not be beneficial to hospitality companies anymore. An overall culture change is required within organizations where individual differences are respected and valued to move forward with the diversity management movement (Martín-Alcázar et al., 2012). Organizations should include diversity management into their strategic plans to reap the full benefits of a diverse workforce.

Companies can initiate programs and policies such as mentoring, diversity training, formal and informal networking groups for their employees to promote a culture of diversity management. Hospitality industry organizations should communicate the importance of diversity management to all employees, encouraging and furthermore rewarding employees for participating in such initiatives. Hospitality organizations should also be committed to providing fair compensation and benefits to all employees, further communicating a "zero tolerance" policy of discrimination. Companies should create a culture where employees' differences are respected and utilized as a strength. As stated previously, Madera (2013) and Gajjar and Okumus (2018) have highlighted a total of ten categories that companies can use as a benchmark for their diversity management practices. By utilizing workforce diversity effectively and as an asset, organizations can generate positive attitudinal and behavioral outcomes among their employees.

\subsection{Limitations and future research}

Despite theoretical and managerial implications, findings from this study must be assessed against a backdrop of potential limitations requiring further research. Additionally, since the research measured employees' perceptions instead of actual performance data, the reality within the workplace may not be entirely reflected through the data. Furthermore, even though the findings were based on a representative sample of hospitality industry employees employed in a range of jobs within several sectors of the industry, generalizing the results must be done with caution because of the country-specific sample. The research should also be replicated to consider the attitudinal and behavioral differences between different groups based on gender, race, ethnicity, etc., by introducing these demographic factors as moderators in future studies.

There is still room for scholars to improve the existing body of knowledge on diversity management. The relationship of diversity management with several desirable organizational outcomes such as organizational citizenship behavior, job satisfaction, organizational commitment and turnover intention should be analyzed. Hsiao et al. (2015) established a positive link between organizational diversity and organizational citizenship behavior. Organizational citizenship behavior is linked with high-involvement human resources management practices at its core (Yang, 2012).
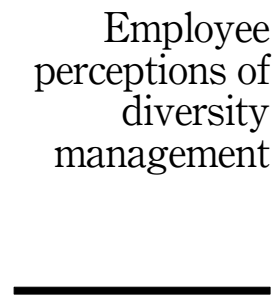
Best practices related to the perceived corporate image, organizational support, organizational justice, internal marketing, organizational culture, training and communication have all been included in diversity management scholarship (Gajjar and Okumus, 2018; Madera, 2013; Madera et al., 2016, 2017) and are crucial in increasing the job satisfaction of hospitality industry employees as highlighted by Kong et al. (2018). Hence, effective diversity management of hospitality industry employees should have a positive impact on employees' job satisfaction.

Although the consequences of employee organizational commitment have been extensively explored in the hospitality industry context, the antecedents have been only broadly researched as organizational characteristics (Luo et al., 2017). A nuanced understanding of precursors of employee organizational commitment, such as diversity management, is lacking in the hospitality scholarship and can be assessed in future studies. Turnover intention or the likelihood of an employee leaving the organization soon (Kang et al., 2015) has also been investigated in the hospitality industry with regards to its several antecedents, a majority of which are organizational characteristics (Ozturk et al., 2014).

\section{References}

Aggarwal, U., Thakore, A. and Bhargava, S. (2010), "Examining the effects social exchange relationships on innovative work behaviour: mediating role of work engagement", 11th International HRM Conference Proceedings, June, UK, Aston University.

Ashikali, T. and Groeneveld, S. (2015), "Diversity management for all? An empirical analysis of diversity management outcomes across groups", Personnel Review, Vol. 44 No. 5, pp. 757-780.

Aytemiz Seymen, O. (2006), "The cultural diversity phenomenon in organisations and different approaches for effective cultural diversity management: a literary review", Cross Cultural Management: An International Journal, Vol. 13 No. 4, pp. 296-315.

Babin, B.J. and Boles, J.S. (1998), "Employee behavior in a service environment: a model and test of potential differences between men and women", The Journal of Marketing, Vol. 62 No. 2, pp. 77-91.

Bakker, A.B. and Bal, M.P. (2010), "Weekly work engagement and performance: a study among starting teachers", Journal of Occupational and Organizational Psychology, Vol. 83 No. 1, Psychology Press, pp. 189-206.

Bakker, A.B. and Leiter, M.P. (2010), "Where to go from here: integration and future research on work engagement”, Work Engagement: A Handbook of Essential Theory and Research, Psychology Press, pp. 181-196.

Bakker, A.B., Hakanen, J.J., Demerouti, E. and Xanthopoulou, D. (2007), "Job resources boost work engagement, particularly when job demands are high", Journal of Educational Psychology, Vol. 99 No. 2, p. 274.

Baqutayan, S.M.S. (2014), "The relationship between conflict management and innovation performance", European Journal of Business and Management, Vol. 6, pp. 90-95.

Best Practices in Achieving Workforce Diversity (2001), Diversity Task Force, available at: https:// govinfo.library.unt.edu/npr/initiati/benchmk/workforce-diversity.pdf.

Bhatnagar, J. (2012), "Management of innovation: role of psychological empowerment, work engagement and turnover intention in the Indian context", The International Journal of Human Resource Management, Vol. 23 No. 5, pp. 928-951.

Buil, I., Martínez, E. and Matute, J. (2016), "From internal brand management to organizational citizenship behaviours: evidence from frontline employees in the hotel industry", Tourism Management, Vol. 57, pp. 256-271. 
Chang, S., Gong, Y. and Shum, C. (2011), "Promoting innovation in hospitality companies through human resource management practices", International Journal of Hospitality Management, Vol. 30 No. 4, pp. 812-818.

Chang, H.T., Hsu, H.M., Liou, J.W. and Tsai, C.T. (2013), "Psychological contracts and innovative behavior: a moderated path analysis of work engagement and job resources", Journal of Applied Social Psychology, Vol. 43 No. 10, pp. 2120-2135.

Chen, W.J. (2011), "Innovation in hotel services: culture and personality", International Journal of Hospitality Management, Vol. 30 No. 1, pp. 64-72.

Chiang, C.F. and Hsieh, T.S. (2012), "The impacts of perceived organizational support and psychological empowerment on job performance: the mediating effects of organizational citizenship behavior", International Journal of Hospitality Management, Vol. 31 No. 1, pp. 180-190.

Cho, S. and Mor Barak, M.E. (2008), "Understanding of diversity and inclusion in a perceived homogeneous culture: a study of organizational commitment and job performance among Korean employees", Administration in Social Work, Vol. 32 No. 4, pp. 100-126.

Choi, S. and Rainey, H.G. (2010), "Managing diversity in US federal agencies: effects of diversity and diversity management on employee perceptions of organizational performance", Public Administration Review, Vol. 70 No. 1, pp. 109-121.

Choi, S. and Rainey, H.G. (2014), "Organizational fairness and diversity management in public organizations does fairness matter in managing diversity?", Review of Public Personnel Administration, Vol. 34 No. 4, pp. 307-331.

Chughtai, A.A. and Buckley, F. (2011), "Work engagement: antecedents, the mediating role of learning goal orientation and job performance", Career Development International, Vol. 16 No. 7, pp. 684-705.

Cooke, F.L. and Saini, D.S. (2010), "How) does the HR strategy support an innovation oriented business strategy? An investigation of institutional context and organizational practices in Indian firms", Human Resource Management, Vol. 49 No. 3, pp. 377-400.

Dhar, R.L. (2015), "The effects of high performance human resource practices on service innovative behaviour", International Journal of Hospitality Management, Vol. 51, pp. 67-75.

Dhar, R.L. (2016), "Ethical leadership and its impact on service innovative behavior: the role of LMX and job autonomy", Tourism Management, Vol. 57, pp. 139-148.

Field, A. (2013), Discovering Statistics Using IBM SPSS Statistics, SAGE Publications, London.

Fornell, C. and Larcker, D.F. (1981), "Structural equation models with unobservable variables and measurement error: algebra and statistics", Journal of Marketing Research, Vol. 18 No. 3, pp. 382-388.

Gajjar, T. and Okumus, F. (2018), "Diversity management: what are the leading hospitality and tourism companies reporting?", Journal of Hospitality Marketing and Management, Vol. 27 No. 8, pp. 905-925.

García-Rodríguez, F.J., Dorta-Afonso, D. and González-de-la-Rosa, M. (2020), "Hospitality diversity management and job satisfaction: the mediating role of organizational commitment across individual differences”, International Journal of Hospitality Management, Vol. 91, 102698.

Garg, S. and Dhar, R. (2017), "Employee service innovative behavior: the roles of leader-member exchange (LMX), work engagement, and job autonomy", International Journal of Manpower, Vol. 38 No. 2, pp. 242-258.

Gottschalg, O. and Zollo, M. (2007), "Interest alignment and competitive advantage", Academy of Management Review, Vol. 32 No. 2, pp. 418-437.

Griggs, L. and Louw, L.L. (Eds) (1995), Valuing Diversity: New Tools for a New Reality, McGraw-Hill Companies.
Employee
perceptions of
diversity
management

$\longrightarrow$ 
Hair, J.F., Black, W.C., Babin, B.J. and Anderson, R.E. (2010), Multivariate Data Analysis, 7th ed., Prentice-Hall, Upper Saddle River, New Jersey, NJ.

Halbesleben, J.R. and Wheeler, A.R. (2008), "The relative roles of engagement and embeddedness in predicting job performance and intention to leave", Work \& Stress, Vol. 22 No. 3, pp. 242-256.

Hayes, A.F. (2009), "Beyond Baron and Kenny: statistical mediation analysis in the new millennium", Communication Monographs, Vol. 76 No. 4, pp. 408-420.

Hight, S.K., Gajjar, T. and Okumus, F. (2019), "Managers from 'Hell' in the hospitality industry: how do hospitality employees profile bad managers?", International Journal of Hospitality Management, Vol. 77, pp. 97-107.

Hon, A. (2011), "Enhancing employee creativity in the Chinese context: the mediating role of employee self-concordance", International Journal of Hospitality Management, Vol. 30 No. 2, pp. 375-384.

Hsiao, A., Auld, C. and Ma, E. (2015), "Perceived organizational diversity and employee behavior", International Journal of Hospitality Management, Vol. 48, pp. 102-112.

Hu, M.-L.M., Horng, J.-S and Sun, Y.-H.C. (2009), "Hospitality teams: knowledge sharing and service innovation performance", Tourism Management, Vol. 30 No. 1, pp. 41-50.

Iacobucci, D., Saldanha, N. and Deng, X. (2007), "A meditation on mediation: evidence that structural equations models perform better than regressions", Journal of Consumer Psychology, Vol. 17 No. 2, pp. 139-153.

Ineson, E.M., Benke, E. and László, J. (2013), "Employee loyalty in Hungarian hotels”, International Journal of Hospitality Management, Vol. 32, pp. 31-39.

Iverson, K. (2000), "Managing for effective workforce diversity: identifying issues that are of concern to employees", The Cornell Hotel and Restaurant Administration Quarterly, Vol. 41 No. 2, pp. 31-38.

Jung, H.S. and Yoon, H.H. (2018), "Improving frontline service employees' innovative behavior using conflict management in the hospitality industry: the mediating role of engagement", Tourism Management, Vol. 69, pp. 498-507.

Kalargyrou, V. and Costen, W. (2017), "Diversity management research in hospitality and tourism: past, present and future", International Journal of Contemporary Hospitality Management, Vol. 29 No. 1, pp. 68-114.

Kalargyrou, V. and Volis, A.A. (2014), "Disability inclusion initiatives in the hospitality industry: an exploratory study of industry leaders", Journal of Human Resources in Hospitality and Tourism, Vol. 13 No. 4, pp. 430-454.

Kang, H.J., Gatling, A. and Kim, J. (2015), "The impact of supervisory support on organizational commitment, career satisfaction, and turnover intention for hospitality frontline employees", Journal of Human Resources in Hospitality and Tourism, Vol. 14 No. 1, pp. 68-89.

Kapoor, C. (2011), "Defining diversity: the evolution of diversity", Worldwide Hospitality and Tourism Themes, Vol. 3 No. 4, pp. 284-293.

Karatepe, O.M. (2013), "High-performance work practices and hotel employee performance: the mediation of work engagement", International Journal of Hospitality Management, Vol. 32, pp. 132-140.

Karatepe, O.M. and Olugbade, O.A. (2009), "The effects of job and personal resources on hotel employees' work engagement”, International Journal of Hospitality Management, Vol. 28 No. 4, pp. 504-512.

Kim, B.Y. (2006), "Managing workforce diversity: developing a learning organization", Journal of Human Resources in Hospitality and Tourism, Vol. 5 No. 2, pp. 69-90. 
Kong, H., Jiang, X., Chan, W. and Zhou, X. (2018), "Job satisfaction research in the field of hospitality and tourism", International Journal of Contemporary Hospitality Management, Vol. 30 No. 5, pp. 2178-2194.

Lee, J.J. and Ok, C.M. (2015), "Drivers of work engagement: an examination of core self-evaluations and psychological climate among hotel employees", International Journal of Hospitality Management, Vol. 44, pp. 84-98.

Lee, J. and Ok, C.M. (2016), "Hotel employee work engagement and its consequences", Journal of Hospitality Marketing and Management, Vol. 25 No. 2, pp. 133-166.

Li, X., Sanders, K. and Frenkel, S. (2012), "How leader-member exchange, work engagement and HRM consistency explain Chinese luxury hotel employees' job performance”, International Journal of Hospitality Management, Vol. 31 No. 4, pp. 1059-1066.

Luo, Z., Marnburg, E. and Law, R. (2017), "Linking leadership and justice to organizational commitment: the mediating role of collective identity in the hotel industry", International Journal of Contemporary Hospitality Management, Vol. 29 No. 4, pp. 1167-1184.

Madera, J.M. (2013), "Best practices in diversity management in customer service organizations an investigation of top companies cited by Diversity Inc", Cornell Hospitality Quarterly, Vol. 54 No. 2, pp. 124-135.

Madera, J.M. (2018), "Situational perspective taking as an intervention for improving attitudes toward organizations that invest in diversity management programs", Journal of Business and Psychology, Vol. 33 No. 3, pp. 423-442.

Madera, J.M., Dawson, M. and Guchait, P. (2016), "Psychological diversity climate: justice, racioethnic minority status and job satisfaction", International Journal of Contemporary Hospitality Management, Vol. 28 No. 11, pp. 2514-2532.

Madera, J.M., Dawson, M. and Neal, J.A. (2017), "Managers' psychological diversity climate and fairness: the utility and importance of diversity management in the hospitality industry", Journal of Human Resources in Hospitality and Tourism, Vol. 16 No. 3, pp. 288-307.

Madera, J.M., Dawson, M. and Neal, J.A. (2018), "Why investing in diversity management matters: organizational attraction and person-organization fit", Journal of Hospitality and Tourism Research, Vol. 42 No. 6, pp. 931-959.

Manoharan, A. and Singal, M. (2017), "A systematic literature review of research on diversity and diversity management in the hospitality literature", International Journal of Hospitality Management, Vol. 66, pp. 77-91.

Manoharan, A., Sardeshmukh, S.R. and Gross, M.J. (2019), "Informal diversity management practices and their effectiveness: in the context of ethnically diverse employees in hotels", International Journal of Hospitality Management, Vol. 82, pp. 181-190.

Manoharan, A., Madera, J.M. and Singal, M. (2021), "Walking the talk in diversity management: exploring links between strategic statements, management practices, and external recognition", International Journal of Hospitality Management, Vol. 94, 102864.

Martín-Alcázar, F., Romero-Fernández, P.M. and Sánchez-Gardey, G. (2012), “Transforming human resource management systems to cope with diversity”, Journal of Business Ethics, Vol. 107 No. 4, pp. 511-531.

Martins, E.C. and Terblanche, F. (2003), "Building organisational culture that stimulates creativity and innovation”, European Journal of Innovation Management, Vol. 6 No. 1, pp. 64-74.

McKay, P.F., Avery, D.R. and Morris, M.A. (2008), "Mean racial-ethnic differences in employee sales performance: the moderating role of diversity climate", Persomnel Psychology, Vol. 61 No. 2, pp. 349-374.

Mistry, T.G. (2019), Employee Perceptions of Diversity Management in the Hospitality and Tourism Industry: Scale Development and Model Testing, [Unpublished doctoral dissertation], University of Central Florida, Orlando.

Mor Barak, M.E., Lizano, E.L., Kim, A., Duan, L., Rhee, M.K., Hsiao, H.Y. and Brimhall, K.C. (2016), "The promise of diversity management for climate of inclusion: a state-of-the-art review and
Employee
perceptions of
diversity
management

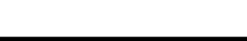


meta-analysis”, Human Service Organizations: Management, Leadership and Governance, Vol. 40 No. 4, pp. 305-333.

Nadda, V., Rahimi, R., Dadwal, S. and Singh, U.B. (2014), "Impact of HR practices on employee's performance: case of UK hotel industry", Journal of Hospitality and Tourism, Vol. 12 No. 2, pp. 88-111.

O'Reilly, C.I., Williams, K.Y. and Barsade, S. (1998), "Group demography and innovation: does diversity help?", in Gruenfeld, D.H. and Gruenfeld, D.H. (Eds), Composition, Elsevier Science/JAI Press, pp. 183-207.

Ottenbacher, M. and Gnoth, J. (2005), "How to develop successful hospitality innovation”, Cornell Hotel and Restaurant Administration Quarterly, Vol. 46 No. 2, pp. 205-222.

Ozturk, A.B., Hancer, M. and Im, J.Y. (2014), "Job characteristics, job satisfaction, and organizational commitment for hotel workers in Turkey", Journal of Hospitality Marketing and Management, Vol. 23 No. 3, pp. 294-313.

Pieterse, A.N., Van Knippenberg, D. and Van Dierendonck, D. (2013), "Cultural diversity and team performance: the role of team member goal orientation", Academy of Management Journal, Vol. 56 №. 3, pp. 782-804.

Pitts, D. (2009), "Diversity management, job satisfaction, and performance: evidence from US federal agencies", Public Administration Review, Vol. 69 No. 2, pp. 328-338.

Presbitero, A. (2017), "How do changes in human resource management practices influence employee engagement? A longitudinal study in a hotel chain in the Philippines", Journal of Human Resources in Hospitality and Tourism, Vol. 16 No. 1, pp. 56-70.

Reade, C. and Lee, H.J. (2016), "Does ethnic conflict impede or enable employee innovation behavior? The alchemic role of collaborative conflict management", International Journal of Conflict Management, Vol. 27 No. 2, pp. 199-224.

Richard, O.C., Murthi, B.P. and Ismail, K. (2007), "The impact of racial diversity on intermediate and long-term performance: the moderating role of environmental context”, Strategic Management Journal, Vol. 28 No. 12, pp. 1213-1233.

Roth, P.L., Huffcutt, A.I. and Bobko, P. (2003), "Ethnic group differences in measures of job performance: a new meta-analysis", Journal of Applied Psychology, Vol. 88 No. 4, p. 694.

Sabharwal, M. (2014), "Is diversity management sufficient? Organizational inclusion to further performance", Public Personnel Management, Vol. 43 No. 2, pp. 197-217.

Saks, A.M. (2006), “Antecedents and consequences of employee engagement”, Journal of Managerial Psychology, Vol. 21 No. 7, pp. 600-619.

Saks, A.M. and Gruman, J.A. (2014), "What do we really know about employee engagement?", Human Resource Development Quarterly, Vol. 25 No. 2, pp. 155-182.

Salanova, M. and Schaufeli, W.B. (2008), "A cross-national study of work engagement as a mediator between job resources and proactive behavior", The International Journal of Human Resource Management, Vol. 19 No. 1, pp. 116-131.

Salanova, M., Agut, S. and Peiró, J.M. (2005), "Linking organizational resources and work engagement to employee performance and customer loyalty: the mediation of service climate", Journal of Applied Psychology, Vol. 90 No. 6, p. 1217.

Schaufeli, W.B. and Bakker, A.B. (2004), "Job demands, job resources, and their relationship with burnout and engagement: a multi-sample study", Journal of Organizational Behavior: The International Journal of Industrial, Occupational and Organizational Psychology and Behavior, Vol. 25 No. 3, pp. 293-315.

Schaufeli, W.B., Salanova, M., González-Romá, V. and Bakker, A.B. (2002), "The measurement of engagement and burnout: a two sample confirmatory factor analytic approach", Journal of Happiness Studies, Vol. 3 No. 1, pp. 71-92.

Schaufeli, W.B., Bakker, A.B. and Salanova, M. (2006), "The measurement of work engagement with a short questionnaire: a cross-national study", Educational and Psychological Measurement, Vol. 66 No. 4, pp. 701-716. 
Shen, J., D’Netto, B. and Tang, J. (2010), “Effects of human resource diversity management on organizational citizen behaviour in the Chinese context", The International Journal of Human Resource Management, Vol. 21 No. 12, pp. 2156-2172.

Singal, M. (2014), "The business case for diversity management in the hospitality industry", International Journal of Hospitality Management, Vol. 40, pp. 10-19.

Employee perceptions of diversity management

Sun, L.Y., Aryee, S. and Law, K.S. (2007), "High-performance human resource practices, citizenship behavior, and organizational performance: a relational perspective", Academy of Management Journal, Vol. 50 No. 3, pp. 558-577.

U.S. Bureau of Labor Statistics (2020), Employed Persons by Detailed Industry, Sex, Race, and Hispanic or Latino Ethnicity, Washington, DC.

Van Knippenberg, D. and Schippers, M.C. (2007), "Work group diversity", Annual Review of Psychology, Vol. 58, pp. 515-541.

Wilborn, L. and Weaver, P. (2002), "Diversity management training initiatives: a profile of current practices within the lodging industry", Journal of Human Resources in Hospitality and Tourism, Vol. 1, pp. 79-96.

Yang, Y.C. (2012), "High-involvement human resource practices, affective commitment, and organizational citizenship behaviors", The Service Industries Journal, Vol. 32 No. 8, pp. 1209-1227.

Yang, Y. and Konrad, A.M. (2011), "Diversity and organizational innovation: the role of employee involvement”, Journal of Organizational Behavior, Vol. 32 No. 8, pp. 1062-1083.

\section{Corresponding author}

Trishna G. Mistry can be contacted at: trishna@usf.edu

For instructions on how to order reprints of this article, please visit our website:

www.emeraldgrouppublishing.com/licensing/reprints.htm

Or contact us for further details: permissions@emeraldinsight.com 